\title{
VOLCANISM IN FRENCH SOMALILAND
}

M. E. AUBERT DE LA RÜE has recently travelled extensively in French Somaliland (November 1937-May 1938) for the purpose of conducting field work, which he has since examined critically (Bull. Volcanolog., ii, 5, 71-108; 1939). It is very plain from the report that volcanism has had an important role in the building up of this region of tropical Africa near the Gulf of Aden. At the moment there is no active volcano in the land but in numerous places there are fumeroles and hydrothermal springs which are the last stages of volcanic activity. In order of age (oldest first) the volcanism may be roughly classified as: (1) Old Basaltic Series, (2) Rhyolitic Series, (3) Recent Basaltic Series, (4) very recent eruptions, and (5) present day volcanic phenomena which include $(a)$ fumeroles and $(b)$ thermal springs.

The Old Basalts in the form of dykes and lava flows were incident after the deposition of the Infracretaceous sandstones. They were observed by $\mathbf{M}$. Dreyfuss in the Ali Sabien mountain complex and they have been observed in the Mabla mountains by M. Dreyfuss and M. Teilhard de Chardin. M. E. Aubert de la Rüe has been able to identify them over a much wider area. In the Issa area they form the base of the Guelileh Valley, and they may be seen under the rhyolite flows of the dissected plateau of Damer-Kada. The Boura mountains, previously considered entirely rhyolitic, in reality have a basaltic base which in places attains an altitude of 750 metres and which is surmounted by tuffs and rhyolitic lava flows. In the Dankali area the Old Basalts appear at the base of the rhyolitic Hassa-Ali chain. They are to be found at the entrance to the Orgoitta Ravine at the foot of the Yagueri Mountains a little to the north of the Yoboki Pass. The series from the base upwards consists of old Basalt, greenish rhyolitic tuff, rhyolitic obsidian, and rhyolite. In places the basalts attain an altitude greater than 1,000 metres. This is so in the high valley of Magaleh and at the col Adhali-Daba to the north of Tadjourah, where they reach a height of 1,140 metres. This Old Basaltic Series is often greatly altered, containing siliceous concretions, calcite veins, zeolites, stillbite and heulandite. When not decomposed the basalt presents a very varied appearance in different localities.

The Old Basalts are followed by the Rhyolitic Series, the age of which is uncertain because there are no sedimentary rocks interstratified with them. M. E. Aubert de la Rüe has been able to show that at least in some places the rhyolites were produced before the basaltic eruptions had ceased. One such case is in the Mabla Mountains where, under the path from Letabolo to Baté-Ero, one can see a rhyolite flow about $10 \mathrm{~m}$. thick between two basalt flows. The Rhyolitic Series may be observed throughout the colony, and does not appear to have a greater thickness than $500 \mathrm{~m}$. The rhyolites, in places prismatic and very fresh, are elsewhere frequently altered. The obsidians are opaque or translucent, grey, grey-green, or black, the latter often having been mistaken for coal. Pantellerite and comendite, described by Lacroix and Arsandaux, have been found near Hol-Hol and in the Mabla Mountains.
The lava flows may be compared with the "coulees stratoïdes' of Yemen described by M. P. Lamare, and have often been eroded into extremely steep pitons. The centres of eruption are most difficult to determine and the different 'Massifs' are regarded not as the vestiges of ancient volcanoes as in the region near Aden but as the remains of rhyolitic plateaux. This agrees with the opinion of P.Lamare, to whom the Mabla massif appears to be a horst.

The rhyolitic series is followed by the Recent Basaltic Series, but in between the deposition of the two was a long interval of time during which a good deal of erosion took place. This may be seen at a number of places but particularly in the valley of Magaleh in the Goudah massif where the whole sequence may be observed. The Recent Basaltic Series appears to be due to a series of fissure eruptions which took place with great regularity. Here and there, between two of the lava flows there exists a well-cemented, reddened conglomerate usually containing pebbles of basalt but sometimes pebbles of rhyolite. The series is fairly uniform, fine grained, and generally having a doleritic texture. It nearly always contains olivine but never in great quantities. Occasionally it is porphyritic with large phenocrists of plagioclase. Some Andesitic flows, chiefly in the Arta massif and near the Koranke-Hada-E-KouriDjabet Mountain, accompany the Recent Basaltic Series. The thickness of the lava in the flows usually varies from $3 \mathrm{~m}$. to $5 \mathrm{~m}$. There are no intercalated tuffs to separate the flows but Aubry found in the Assal Basin under 200 metres of labradorite a lacustrine sedimentary deposit with Unio, Corbicules, Limnées, Planorbes and Mélanies about three metres thick. Similar phenomena have been observed elsewhere in the colony. The smallish volcanic cones visible from Djibouti in the region to the south-west have been formed by scoriaceous lavas and are of mixed Strombolian-Hawaiian type. Perhaps Mount Garbi is a volcanic cone, and if so it is the largest in French Somaliland $(1,650 \mathrm{~m}$.$) .$

It is difficult to draw a demarcation line between the Recent Basaltic Series and the very recent eruptions, but it is probable that man was already on the earth when the volcanoes of Ghoubet-elKharab erupted. The basaltic flows, interstratified with the Quaternary cones of dejection at the lower end of the slopes of the Mabla Mountains, are probably fairly recent and have been affected by very recent faults in the valley of west Ababoléi. The last stages of volcanic activity may be found in the fumeroles and hot springs now existing. A typical fumerole is in the south-east of the plain of Hanleh about $3 \mathrm{~km} .500 \mathrm{~m}$. to the east-north-east of Garbes. It is called by the Danakils 'the smoking mountain' and consists of a band a few score metres wide and about 400 metres long orientated in a north-westsouth-east direction. In this region the basalt has been largely decomposed to a red clay which is often at a temperature of $100^{\circ} \mathrm{C}$. Aqueous sulphurous vapour at $100^{\circ} \mathrm{C}$. escapes from the ground through a multitude of small fissures sometimes silently and at other times with a slight whistle. Near the region there are incrustations of white gypsum, saccharoïde and kalinite. 
There are numerous regions with hot springs in the colony. A typical one is at Asbahalto on the eastern bank of Lake Abbé, called by the Danakils 'the evil smelling water'. Here innumerable thermal springs have deposited walls of travertin which have the appearance of ruins, about 5-10 m. high on the average. This travertin is composed chiefly of calcium carbonate together with a little magnesium carbonate. Superficially it is clear grey whilst in the interior it is yellowish white, having a spongy structure and being somewhat friable. The denticulated walls and small pitons are aligned roughly east-west and probably follow the fault lines. A spring at the foot of Badikoma has a temperature of $100^{\circ} \mathrm{C}$., gave a fairly alkaline reaction and when evaporated left a residue of $2.48 \mathrm{gm}$. per litre. This consisted of silica $0.090 \mathrm{gm}$., calcium carbonate $0 \cdot 109 \mathrm{gm}$., calcium sulphate $0.485 \mathrm{gm}$., magnesium chloride $0.032 \mathrm{gm}$., potassium chloride $0.054 \mathrm{gm}$., sodium chloride $\mathbf{1 . 6 4 8} \mathrm{gm}$., sodium bromide 0.0035 gm., together with organic and miscellaneous material $0.0585 \mathrm{gm}$. Other hot springs abound in the plain of Hanleh, in the valley of west Kouri, in Goum, Halol, and in Obock.

\section{FOREST PRODUCTS RESEARCH BOARD}

\begin{abstract}
THE report for 1938 of the Forest Products Research Board recently issued (London : H.M. Stationery Office, 1939. 1s. 6d. net) is dated June 1939. Remembering that the outbreak of war was to come so soon after its completion, there are one or two points which appear to merit particular mention. The chief, perhaps, is the research on composite wood, for which the Board had had under consideration detailed proposals for the provision of equipment.

The interest which this subject has aroused would seem to indicate that all the substitutes which have replaced wood have apparently had little influence upon the great demands still being made on the forest. The Board's report states, with reference to composite wood: "We are impressed with the need for systematic research on the properties of this class of materials in order to build a foundation of technical knowledge such as has been accumulated in the case of 'solid' wood by many years of work at various universities and laboratories in the past." In view of the importance which the processes of manufacture and the interrelations of the materials used have on the properties of the final products, the need for systematic research is evident. New methods of test and investigation may have to be developed to
\end{abstract}

deal with these products, the properties of which differ fundamentally from those of 'solid wood'. Inquiries regarding these products were rapidly increasing, even though the laboratory has disclaimed possession of any real technical knowledge of them. The industries interested cover every field in which natural wood has hitherto been used, and several in which the use of wood has practically been abandoned.

The report of the Director of Forest Products Research is issued with the above. Inquiries in every department of the Laboratory's activities continued to be numerous. As one example of the work undertaken, the experimental work on the production of charcoal in portable steel kilns is proving suecessful. Charcoal is being increasingly used for various industrial purposes, particularly in the manufacture of Rayon; and the manufacturer in Great Britain has been very dependent on foreign supplies of it. Hitherto, charcoal which has been made in portable kilns has contained too great a percentage of volatile matter ; the experimental kiln now in use is said to go far in removing this objection. A leading firm of Rayon manufacturers has stated that charcoal pro duced by certain burnings is equal to the best obtainable from any source.

\section{CORTICAL LOCALIZATION OF INTELLIGENCE}

$\mathrm{H}$ M. HILDRETH, at the meeting of the American . Association for the Advancement of Science, Columbus, Ohio, December 1939, presented a statistical study of the cortical localization of intelligence.

The problem involves the correlation of an independent physiological variable with a dependent psychological variable. Since in studying human beings it is not possible to destroy predetermined parts of the cortex by operation, an experimental group of individuals whose brains had been damaged by disease or by natural organic changes had to be used. The psychological variable could be measured by using well-established tests of intelligence. The group studied consisted of individuals found to be suffering from cerebral arteriosclerosis, in which disease small areas, apparently occurring at random, are destroyed throughout the brain. From a psychopathic hospital of 4,000, all the patients who after complete examination were found to be suffering from this disease were selected, and from this group were eliminated those who showed signs of any disease, for example, brain tumour, that might conceivably affect intelligence. This gave a selected experimental group of 201 subjects. A control group of 201 normal individuals was also selected, comparable except that they had no signs of arteriosclerosis. Previous records of intelligence and school attainments were available.

It is argued that if all the subjects are now given an intelligence test, since the two groups are matched, then the performance of the normal group might be taken as what the other group would have been if it were not suffering from arteriosclerosis. 